\title{
Determinan Indeks Pembangunan Manusia di Klaster Daerah Cepat Maju dan Cepat Tumbuh di Provinsi Jawa Timur
}

\author{
Indah Purnama Sari ${ }^{1}$, Zaeni Miftah ${ }^{2}$ \\ ${ }_{1}^{1}$ Fakultas IImu Pendidikan dan Pengetahuan Sosial, Universitas Indraprasta PGRI \\ 2 Program Studi Sistem Informasi, STIKOM Cipta Karya Informatika
}

\begin{tabular}{l}
\hline ARTICLE INFO \\
\hline Article History: \\
Received May $16^{\text {th }}, 2021$ \\
Revised July $15^{\text {th }}, 2021$ \\
Accepted Aug $13^{\text {th }}, 2021$
\end{tabular}

\section{Keywords:}

$\mathrm{HDI}$;

Unemployment;

Gini Ratio;

Density;

Klassen's Typology.

\begin{abstract}
This study examines the determinants of $\mathrm{HDI}$ in Fast-Developing and FastGrowing Regions. The research was carried out in 2020 in East Java Province, by previously dividing East Java into four regional categories, namely Fast Forward and Fast-Growing Areas, Fast Developing Areas, Developed But Depressed Areas, and Relatively Disadvantaged Areas. This study used a cluster analysis research design and comparative causal analysis. HDI determinants analyzed include variables: unemployment, Gini ratio, and population density. The number of samples used was 66-panel data samples from 11 districts/cities with crosssection data and 6 years of time-series data. The data used are secondary data from East Java BPS, then analyzed by panel data regression method. The findings of the study are that in the Fast-Developing and Fast-Growing Areas, unemployment, Gini ratio, and population density simultaneously have a significant effect on HDI; unemployment has a significant negative effect on $\mathrm{HDI}$; Gini ratio has a significant positive effect on $\mathrm{HDI}$, and population density has a significant positive effect on $\mathrm{HDI}$.
\end{abstract}

Penelitian ini mengkaji determinan IPM di Daerah Cepat Maju dan Cepat Tumbuh. Penelitian dilaksanakan pada tahun 2020 di Provinsi Jawa Timur, dengan sebelumnya membagi Jawa Timur menjadi empat kategori wilayah, yaitu Daerah Cepat Maju dan Cepat Tumbuh, Daerah Berkembang Cepat, Daerah Maju Tetapi Tertekan, dan Daerah Relatif Tertinggal. Penelitian ini menggunakan desain penelitian analisis klaster dan analisis kausal komparatif. Determinan IPM yang dianalisis meliputi variabel: penggangguran, gini rasio, dan kepadatan penduduk. Jumlah sampel yang digunakan sebanyak 66 sampel data panel yang berasal dari 11 kabupaten/kota data cross section dan 6 tahun data time series. Data yang digunakan adalah data sekunder dari BPS Jawa Timur, kemudian dianalisis dengan metode regresi data panel. Temuan penelitian adalah di Daerah Cepat Maju dan Cepat Tumbuh, pengangguran, gini rasio, dan kepadatan penduduk secara simultan berpengaruh signifikan terhadap IPM; pengangguran berpengaruh negatif signifikan terhadap IPM; gini rasio berpengaruh positif signifikan terhadap IPM; dan kepadatan penduduk berpengaruh positif signifikan terhadap IPM.

\section{Corresponding Author:}

Indah Purnama Sari,

Email: indah.purnamasari@unindra.ac.id

How to Cite: Sari, I.P., Miftah, Z. (2021).Determinan indeks pembangunan manusia di klaster daerah cepat maju dan cepat tumbuh di Provinsi Jawa Timur . Sosio e-Kons, 13 (2),87-98.http://dx.doi.org/10.30998/sosioekons.v13i2.9760

\section{PENDAHULUAN}

Kemajuan suatu negara tidak hanya dilihat dari sisi keberhasilan pembangunan di bidang ekonomi, melainkan juga harus dilihat dari sejauh mana negara mampu membangun manusianya. 
Pembangunan yang berpusat pada manusia akan menghadirkan lingkungan yang kondusif sehingga masyarakat dapat hidup sehat, panjang umur, berpengetahuan luas, dan produktif.

Indeks Pembangunan Manusia (IPM) merupakan konsep pengukuran pembangunan manusia di Indonesia dengan tiga dimensi dasar yaitu umur panjang dan sehat, pengetahuan, dan kehidupan yang layak (BPS, 2015). Ketiganya terkait dengan banyak faktor sehingga memiliki pengertian yang luas. Angka IPM dibentuk dari empat komponen sebagai determinan utama IPM yaitu: angka harapan hidup saat lahir, harapan lama sekolah, rata-rata lama sekolah, dan pengeluaran per kapita (BPS, 2015).

Berdasarkan hasil kajian empiris, tinggi rendahnya angka IPM ditentukan oleh beberapa determinan, diantaranya: gini rasio, kriminalitas (Yolanda et. al., 2020), anggaran pendidikan, pendapatan per kapita (Bintang P et. al., 2015); Gross Domestic Product (GDP) per kapita, literacy rate, life expectancy at birth, gini index, fertility rate, and $\mathrm{CO}_{2}$ emission (Shah, 2016); violent crime rate, percent use of renewable energy (Anderson, 2014); unemployment (Taner et. al., 2011); Gross Regional Domestic Product (GRDP), illiterate population (Sembada et. al., 2019); population density (Qasim dan Chaudary, 2015).

Jawa Timur merupakan salah satu provinsi yang sangat menarik untuk dikaji, selain karena kondisi geografisnya yang terdiri dari Jawa daratan dan Pulau Madura, Jawa Timur merupakan Provinsi Pertumbuhan ekonomi selalu di atas pertumbuhan ekonomi nasional dan penyumbang terbesar kedua pada PDB. Melalui kajian ini peneliti ingin menganalisis bagaimana pengaruh pengangguran, gini rasio dan kepadatan penduduk terhadap Indeks Pembangunan Manusia di klaster Daerah Cepat Maju dan Cepat Tumbuh di Provinsi Jawa Timur. Hal ini mengingat klaster Daerah Cepat Maju dan Cepat Tumbuh merupakan kutub pertumbuhan ekonomi di Provinsi Jawa Timur.

\section{METODE}

Populasi dalam penelitian ini adalah Klaster Daerah Cepat Maju dan Cepat Tumbuh di Provinsi Jawa Timur meliputi 11 kabupaten/kota. Seluruh anggota populasi dalam penelitian ini dijadikan sampel, teknik sampling yang digunakan adalah teknik sampel jenuh (metode sensus). Adapun pemilihan periode tahun analisis berdasarkan pertimbangan Indonesia mengaplikasikan metode perhitungan IPM yang baru sejak tahun 2014. Oleh karena itu diambil permulaan tahun data penelitian adalah 2014 sampai dengan tahun 2019. Dengan demikian jumlah sampel yang digunakan dalam penelitian ini adalah 11 kabupaten/kota $\times 6$ tahun $=66$ sampel data panel.

Untuk menentukan Klaster Daerah Cepat Maju dan Cepat Tumbuh dalam penelitian ini menggunakan klasterisasi berdasarkan tipologi klassen. Klaster Daerah Cepat Maju dan Cepat Tumbuh merupakan klaster yang berada di Kuadran I, dengan ciri memiliki tingkat pertumbuhan ekonomi dan tingkat pendapatan yang lebih tinggi dibanding rata-rata kabupaten/kota.

Berdasarkan kerangka berpikir, dalam desain penelitian kausal ini menggunakan struktur model sebagai berikut :

$$
\ln \left(I P M_{i t}\right)=\alpha+\beta_{1} \ln \left(T P T_{i t}\right)+\beta_{2} \ln \left(G R_{i t}\right)+\beta_{3} \ln \left(K P_{i t}\right)+e_{i t}
$$

Teknis analisis dalam penelitian dimulai dengan menguji stationeritas data menggunakan LLC (Levin, Lin \& Chu), menentukan model estimasi, memilih model estimasi terbaik, menguji signifikansi (hipotesis) dan Goodness of Fit. Selain itu dilakukan uji kelayakan model. Menurut pendapat Koutsoyiannis dan Wirasasmita (2008 yang dikutip oleh Amir, 2015) bahwa terdapat empat aspek minimal yang harus dipenuhi dalam uji kelayakan model ekonometrika, yakni : Theoretical plausibility, Accuracy of the estimates of the parameters, Explanatory ability, dan Forecasting ability.

Bagian metode harus dapat menjelaskan metode penelitian yang digunakan, termasuk bagaimana rancangan kegiatan, prosedur pelaksanaannya, dan ruang lingkup atau obyek. Alat utama, bahan, tempat, pengumpulan data, media atau instrumen penelitian, dan teknik analisis harus 
dijelaskan dengan baik. Apabila ada rumus statistika yang digunakan sebagai bagian dari metode penelitian, sebaiknya tidak menuliskan rumus yang sudah berlaku umum.

\section{HASIL DAN PEMBAHASAN}

\section{Hasil}

Berdasarkan perhitungan, didapatkan rata-rata pertumbuhan ekonomi di Provinsi Jawa Timur periode 2014-2019 adalah 5,56, sedangkan rata-rata IPM periode 2014-2019 adalah 69,90. Dengan demikian, dapat disajikan diagram kartesius tipologi Klassen (Gambar 1) dengan Kuadran I (Daerah Cepat maju dan Cepat Tumbuh) meliputi: Kab. Sidoarjo, Kab. Mojokerto, Kab. Lamongan, Kab. Gresik, Kota Blitar, Kota Malang, Kota Probolinggo, Kota Mojokerto, Kota Madiun, Kota Surabaya, Kota Batu.

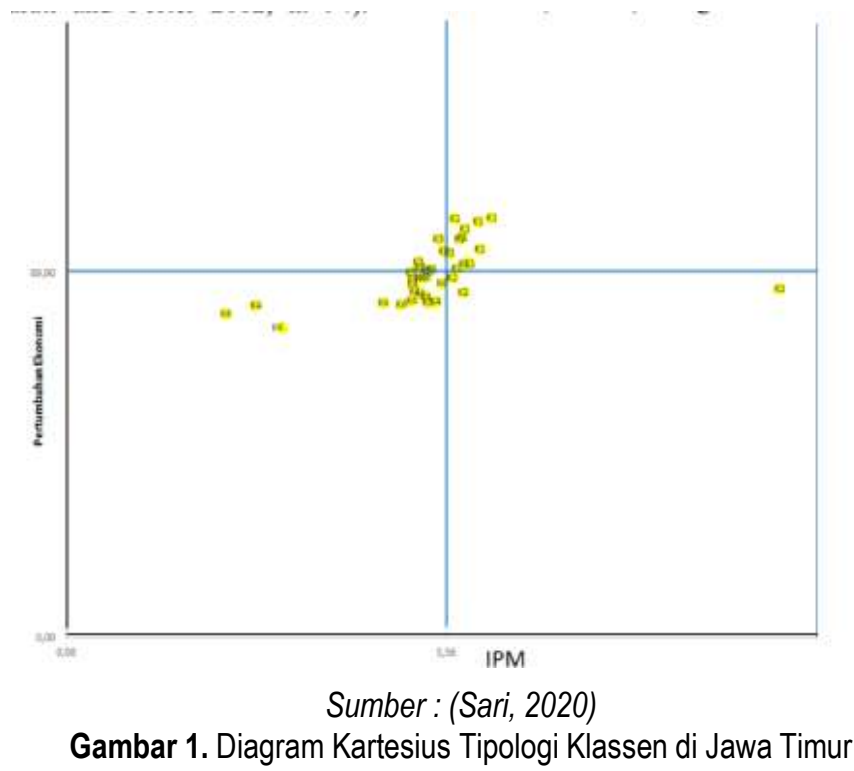

Hasil uji Unit Root untuk setiap variabel pada struktur model menunjukkan bahwa data telah stationer pada tingkat level atau pada tingkat first difference. Berdasarkan hasil tersebut, analisis regresi antara variabel akan memberikan hasil yang dapat diandalkan karena data yang digunakan bersifat stationer dan terhindar dari spurious regression.

Berdasarkan pendekatan common effect, fixed effect, dan random effect didapatkan hasil untuk Kuadran I (Klaster Daerah Cepat Maju dan Cepat Tumbuh) sebagai berikut:

Tabel 1.

Model Estimasi

\begin{tabular}{lccc}
\hline \multicolumn{1}{c}{ Item } & CEM & FEM & REM \\
\hline Model & $\ln (I P M)=4,21+0,04 \ln (T P T)$ & $\ln (I P M)=4,15-0,02 \ln (T P T)$ & $\ln (I P M)=4,14-0,02 \ln (T P T)$ \\
Persamaan & $+0,13 \ln (G R)+0,02 \ln (K P)$ & $+0,08 \ln (G R)+0,04 \ln (K P)$ & $+0,08 \ln (G R)+0,04 \ln (K P)$ \\
& & & $-2,00^{* *}$ \\
$t$-stat $T P T$ & $2,45^{* *}$ & $-2,43^{* *}$ & $4,30^{* *}$ \\
$t$-stat GR & $2,29^{* *}$ & $4,21^{* *}$ & $4,72^{* *}$ \\
$t$-stat $K P$ & $2,77^{* *}$ & $2,84^{* *}$ & $16,27^{* *}$ \\
F-statistic & $30,25^{* *}$ & $120,01^{* *}$ & 0,52 \\
Adjusted $R^{2}$ & 0,67 & 0,97 & \\
\hline
\end{tabular}

note: ${ }^{*}<0,1,{ }^{* *}<0,05,{ }^{* * *}<0,1, t$-stat in parentheses

Sumber : (Data diolah, 2020)

Dari ketiga pendekatan tersebut kemudian dipilih model terbaik diantara CEM dan FEM dengan melakukan Uji Likelihood Ratio dengan hasil sebagai berikut : 
Tabel 2

Hasil Uji Likelihood Ratio

\begin{tabular}{lrrr}
\hline Effects Test & Statistic & d.f. & Prob. \\
\hline Cross-section F & 45.644196 & $(10,30)$ & 0.0000 \\
Cross-section Chi-square & 122.580489 & 10 & 0.0000 \\
Sumber : Data diolah, 2020 & & &
\end{tabular}

Berdasarkan Uji Likelihood Ratio, karena $p$ value chi square $0,00<0,05$ maka model FEM lebih baik. Selanjutnya memilih model terbaik diantara model FEM dan REM dengan melakukan Uji Hausman, dengan hasil sebagai berikut:

Tabel 3

Hasil Uji Hausman

\begin{tabular}{lrrr}
\hline Test Summary & Chi-Sq. Statistic & Chi-Sq. d.f. & Prob. \\
\hline & & & \\
Cross-section random & 8.001272 & 3 & 0.0460 \\
\hline
\end{tabular}

Sumber: (Data diolah, 2020)

Berdasarkan Uji Hausman, $p$ value cross section random $0,04<0,05$, maka model terbaik yang terpilih adalah model FEM. Model Fixed Effect ini mengasumsikan perilaku individu kabupaten/kota berbeda. Dengan demikian koefisien intersep berbeda dan slope sama antar waktu dan antar kabupaten/kota.

Tabel 4.

Hasil Estimasi Fixed Effect

Method: Pooled Least Squares

Date: 07/25/20 Time: 15:26

Sample (adjusted): 14

Included observations: 4 after adjustments

Cross-sections included: 11

Total pool (balanced) observations: 44

\begin{tabular}{crrrr}
\hline Variable & Coefficient & Std. Error & t-Statistic & Prob. \\
\hline C & 4.151698 & 0.106582 & 38.95292 & 0.0000 \\
TPT? & -0.020059 & 0.008243 & -2.433542 & 0.0211 \\
GR? & 0.076209 & 0.018094 & 4.211917 & 0.0002 \\
KP? & 0.035388 & 0.012460 & 2.840108 & 0.0080 \\
Fixed Effects (Cross) & & & & \\
BATU-C & -0.002382 & & \\
BLITARKOTA-C & -0.009108 & & \\
GRESIK-C & 0.029046 & & \\
LAMONGAN-C & -0.010220 & & \\
MADIUNKOTA-C & 0.031178 & & \\
MALANGKOTA-C & 0.028994 & & \\
MOJOKERTO-C & -0.018901 & & \\
MOJOKERTOKOTA-C & -0.028387 & & \\
PROBOLINGGOKOTA-C & -0.069994 & & \\
SIDOARJO-C & 0.031968 & & \\
SURABAYA-C & 0.017807 & & \\
R-squared & 0.981134 & Mean dependent var & \\
Adjusted R-squared & 0.972959 & S.D. dependent var & \\
S.E. of regression & 0.007934 & Akaike info criterion & -6.581865 \\
Sum squared resid & 0.001889 & Schwarz criterion & -6.014169 \\
Log likelihood & 158.8010 & Hannan-Quinn criter. & -6.371336 \\
F-statistic & 120.0132 & Durbin-Watson stat & 1.378988 \\
Prob(F-statistic) & 0.000000 & & \\
\hline Sumber : (Datadiolah, 2020) & & & \\
\hline
\end{tabular}

Sumber : (Data diolah, 2020) 
Hasil uji $F$ menunjukkan model layak, dengan nilai $F$ stat 120,01 dan prob (F-stat) 0,00 . Hasil ini juga bermakna semua variabel bebas (pengangguran, gini rasio, kepadatan penduduk) secara simultan berpengaruh signifikan terhadap variabel IPM.

Hasil regresi Fixed Effect menunjukkan bahwa tanda variabel pengangguran adalah negatif, menunjukkan variabel pengangguran berhubungan negatif dengan variabel IPM. Hal ini sesuai dengan yang diharapkan teori. Adapun variabel Gini Rasio dan Kepadatan Penduduk bertanda positif, menunjukkan berhubungan positif terhadap variabel IPM, juga sesuai dengan yang diharapkan teori. Nilai koefisien untuk variabel pengangguran $-0,02$ secara statistik signifikan melalui uji t pada $a=5 \%$ dengan nilai t stat $-2,43$. Nilai koefisien variabel Gini Rasio 0,08 secara statistik signifikan melalui uji t pada $a=5 \%$ dengan nilai $t$ stat 4,21. Nilai koefisien variabel Kepadatan Penduduk 0,04 secara statistik signifikan melalui uji t pada $a=5 \%$ dengan nilai $t$ stat 2,84. Hal ini berarti pengangguran berpengaruh negatif terhadap IPM. Adapun Gini Rasio dan Kepadatan Penduduk berpengaruh positif terhadap IPM.

Intersep untuk klaster Daerah Cepat Maju dan Cepat Tumbuh sebesar 4,15 bermakna jika variabel pengangguran, gini rasio, dan kepadatan penduduk tidak berubah maka IPM konstan pada tingkat 4,15\%. Adapun intersep untuk masing-masing kabupaten/kota adalah sebagai berikut : intersep Kota Batu 4,15; intersep Kota Blitar 4,14; intersep Kabupaten Gresik 4,18; intersep Kabupaten Lamongan 4,14; intersep Kota Madiun 4,18; intersep Kota Malang 4,18; intersep Kabupaten Mojokerjo 4,13; intersep Kota Mojokerto 4,12; intersep Kota Probolinggo 4,08; intersep Kabupaten Sidoarjo 4,18; intersep Kota Surabaya 4,17. Berdasarkan intersep ini dapat disusun persamaan regresi untuk tiap kabupaten/kota diantaranya sebagai berikut:

$$
\begin{aligned}
& \ln \left(I P M_{\text {KotaMojokerto }}\right)=4,12-0,02 \ln (T P T)+0,08 \ln (G R)+0,04 \ln (K P) \\
& \ln \left(I P M_{\text {KotaBlitar }}=4,14-0,02 \ln (T P T)+0,08 \ln (G R)+0,04 \ln (K P)\right. \\
& \ln \left(I P M_{\text {KabMojokerto }}\right)=4,13-0,02 \ln (T P T)+0,08 \ln (G R)+0,04 \ln (K P) \\
& \text { Pada persamaan klaster didapatkan } \ln (I P M)=4,15-0,02 \ln (T P T)+0,08 \ln (G R)+0,04 \ln (K P)
\end{aligned}
$$
dapat dimaknai bahwa yang akan terjadi di klaster ini ketika tingkat pengangguran naik $1 \%$ maka IPM akan turun sebesar $0,02 \%$, faktor lain diasumsikan tetap. Kemudian jika Gini Rasio naik $1 \%$ maka IPM akan naik 0,08\%, faktor lain diasumsikan tetap. Adapun jika Kepadatan Penduduk naik 1\% maka IPM akan naik $0,04 \%$, faktor lain diasumsikan tetap. Nilai koefisien determinasi yang disesuaikan (Adjusted $R^{2}$ ) sebesar 0,97 yang berarti model mampu menjelaskan variasi IPM sebesar $97 \%$. Adapun $3 \%$ lainnya dapat dijelaskan oleh variabel lain.

Berdasarkan uji kelayakan model, struktur model telah memenuhi semua uji kelayakan model, sebagai berikut:

1. Theoretical Plausibility

Tabel 5.

Hasil Uji Theoretical Plausibility

\begin{tabular}{lccc}
\hline \multicolumn{1}{c}{ Hubungan Antar Variabel } & Pra Estimasi & Pasca Estimasi & Simpulan \\
\hline Pengangguran berpengaruh terhadap IPM & $(-)$ & $(-)$ & Sesuai \\
Gini rasio berpengaruh terhadap IPM & $(+)$ & $(+)$ & Sesuai \\
Kepadatan penduduk berpengaruh terhadap IPM & $(+)$ & $(+)$ & Sesuai \\
\hline
\end{tabular}

Sumber : (Data diolah, 2020)

2. Accuracy of the estimates of the parameters

Tabel 6.

Hasil Uji Accuracy of The Estimates of The Parameters

\begin{tabular}{lcc}
\hline \multicolumn{1}{c}{ Hubungan Antar Variabel } & p-value & Simpulan \\
\hline Pengangguran berpengaruh terhadap IPM & 0,02 & Signifikan pada a 0,05 \\
Gini rasio berpengaruh terhadap IPM & 0,00 & Signifikan pada a 0,05 \\
Kepadatan penduduk berpengaruh terhadap IPM & 0,01 & Signifikan pada a 0,05 \\
\hline
\end{tabular}

Sumber: (Data diolah, 2020) 


\section{Explanatory ability}

Tabel 7.

Hasil Uji Explanatory Ability

\begin{tabular}{lccc}
\hline \multicolumn{1}{c}{ Hubungan Antar Variabel } & $\begin{array}{c}\text { Koefisien } \\
\text { Regresi }\end{array}$ & $\begin{array}{c}\text { Standard } \\
\text { Error }\end{array}$ & Kesimpulan \\
\hline Pengangguran berpengaruh terhadap IPM & $-0,020696$ & 0,008243 & $0,008243<1 / 2 \beta$ \\
Gini rasio berpengaruh terhadap IPM & 0,068690 & 0,018094 & $0,018094<1 / 2 \beta$ \\
Kepadatan penduduk berpengaruh terhadap IPM & 0,037733 & 0,012460 & $0,012460<1 / 2 \beta$ \\
\hline
\end{tabular}

Sumber : (Data diolah, 2020)

4. Forecasting ability

Tabel 8.

Hasil Uji Forecasting Ability

\begin{tabular}{ccc}
\hline Struktur Model & Adjusted R-Square & Kesimpulan \\
\hline $\ln \left(I P M_{i t}\right)=a+\beta_{1} \ln \left(T P T_{i t}\right)+\beta_{2} \ln \left(G R_{i t}\right)+$ \\
$\beta_{3} \ln \left(K P_{i t}\right)+e_{i t}$ & $0,97(97 \%)$ & Lebih dari $50 \%$ \\
\hline Sumber : Data diolah, 2020 & &
\end{tabular}

\section{Pembahasan}

Daerah Cepat Maju dan Cepat Tumbuh dengan ciri pertumbuhan ekonomi tinggi dan pendapatan per kapita tinggi diisi oleh 4 kabupaten dan 7 kota, yaitu Kabupaten Sidoarjo, Kabupaten Mojokerto, Kabupaten Lamongan, Kabupaten Gresik, Kota Malang, Kota Probolinggo, Kota Mojokerto, Kota Madiun, Kota Surabaya, dan Kota Batu. Sebelas daerah ini memiliki ciri IPM dan pertumbuhannya di atas rata-rata Jawa Timur. Kendati mayoritas diisi daerah kategori kota, 4 daerah kategori kabupaten di klaster ini merupakan bagian metropolitan dari Jawa Timur yang dikenal dengan istilah Gerbangkertosusila (akronim dari Gresik, Bangkalan, Mojokerto, Surabaya, Sidoarjo, dan Lamongan). Gerbangkertosusila berpusat di Kota Surabaya dan merupakan wilayah metropolitan terbesar kedua di Indonesia setelah Jabodetabek yang berpusat di Jakarta. Dengan kata lain, Gerbangkertosusila juga merupakan kawasan perkotaan, dimana kegiatan utamanya bukan pertanian dan susunan fungsi kawasan sebagai tempat permukiman perkotaan, pemusatan dan distribusi pelayanan jasa pemerintahan, pelayanan sosial, dan kegiatan ekonomi.

Daerah Cepat Maju dan Cepat Tumbuh memiliki berbagai potensi pengembangan wilayah, misalnya : 1) Potensi perikanan budidaya air payau (kawasan Ujung Pangkah dan Panceng di Kabupaten Gresik, serta Sedati di Kabupaten Sidoarjo dengan komoditas ikan bandeng); potensi perikanan budidaya air tawar di Kabupaten Lamongan; potensi garam di Kabupaten Gresik, Kabupaten Lamongan, dan Kota Surabaya; 2) Potensi pertambangan minyak dan gas bumi di Kabupaten Gresik, Kabupaten Lamongan, Kabupaten Sidoarjo, dan Kota Surabaya; Potensi panas bumi di Songgoriti (Kota Batu), Bromo-Tengger (Kota Malang), Pulau Bawean (Kabupaten Gresik); 3) Potensi pariwisata; serta 4) Potensi industri yang sedang dikembangkan menjadi kawasan industri skala besar dan berhubungan dengan pangsa pasar eksport (Kota Surabaya, Kabupaten Mojokerto, Kabupaten Gresik, dan Kabupaten Sidoarjo).

a. Pengangguran, gini rasio, dan kepadatan penduduk secara simultan berpengaruh signifikan terhadap IPM di Daerah Cepat Maju dan Cepat Tumbuh (High Growth High Income) di Jawa Timur

Berdasarkan nilai probabilitas pada $F$ statistik signifikan pada a $5 \%$, maka terbukti pengangguran, gini rasio, dan kepadatan penduduk secara simultan berpengaruh signifikan terhadap IPM di Daerah Cepat Maju dan Cepat Tumbuh. Adapun besaran pengaruh variabel pengangguran, gini rasio, dan kepadatan penduduk secara simultan terhadap IPM di Kuadran I (Daerah Cepat Maju dan Cepat Tumbuh) adalah 97 persen, sisanya 3 persen dipengaruhi oleh variabel di luar variabel penelitian. Dengan demikian Hipotesis 1 diterima (terbukti). Untuk 
meningkatkan IPM di klaster ini pemerintah daerah perlu menekan angka pengangguran, sekaligus menjaga gini rasio berada di kategori sedang, dan kepadatan penduduk menjadi peluang pasar yang sangat potensial. Jika pengangguran di klaster ini turun, gini rasio naik, begitu juga kepadatan penduduk naik maka IPM akan meningkat. Menurunnya pengangguran akan menambah pendapatan di masyarakat, pendapatan yang meningkatkan akan meningkatkan gini rasio, namun hal ini berpengaruh positif sebab peningkatan pendapatan di kawasan padat penduduk justru meningkatkan pengeluaran konsumsi di masyarakat yang berakibat pada perputaran ekonomi yang cepat yang pada akhirnya akan meningkatkan kesejahteraan masyarakat (IPM).

\section{b. Pengangguran berpengaruh negatif signifikan terhadap IPM di Daerah Cepat Maju dan Cepat Tumbuh (High Growth High Income) di Jawa Timur}

Berdasarkan uji statistik, variabel pengangguran terbukti berpengaruh signifikan terhadap IPM di Daerah Cepat Maju dan Cepat Tumbuh berdasarkan nilai t statistik yang signifikan pada a $5 \%$. Apabila melihat tanda (arah) pada koefisien yang bertanda negatif menunjukkan bahwa pengangguran berpengaruh negatif signifikan terhadap IPM di klaster ini. Ketika tingkat pengangguran menurun, di sisi lain IPM mengalami peningkatan. Dengan demikian Hipotesis 2 diterima (terbukti).

Selain perkotaan, Daerah Cepat Maju dan Cepat Tumbuh juga merupakan daerah pusat industri. Karenanya wajar apabila klaster ini mampu menyerap tenaga kerja lebih banyak sehingga pengangguran berkurang. Dengan berkurangnya pengangguran di sisi lain IPM bergerak naik. Apabila ditinjau dari pencapaian IPM, klaster ini memiliki IPM di atas rata-rata, yang mencerminkan sejauh mana kualitas manusia atau kesejahteraan masyarakat.

Berkurangnya pengangguran akan menambah jumlah pendapatan di masyarakat sehingga kemakmuran masyarakat bertambah, daya beli masyarakat meningkat, dan kebutuhan dasar lain seperti pendidikan dan kesehatan dapat tercukupi sehingga dapat meningkatkan kualitas manusia. Adapun sebaliknya jika jumlah pengangguran semakin tinggi akan mengurangi kemakmuran masyarakat karena pengangguran menyebabkan berkurangnya pendapatan yang ada dalam masyarakat. Ketika tingkat pengangguran semakin menurun, IPM di Daerah Cepat Maju dan Cepat Tumbuh justru mengalami peningkatan. Hal ini sesuai dengan teori dari Sukirno (2019) yang menyatakan bahwa seorang pengangguran tingkat kemakmurannya rendah karena tidak memiliki pendapatan, sedangkan pendapatan merupakan salah satu faktor penting yang menentukan kemakmuran. Dengan kata lain, kondisi menganggur menyebabkan kesejahteraan menurun, seseorang tidak bisa menikmati kehidupan yang layak. Oleh karena itu pengangguran berpengaruh negatif terhadap upaya pembangunan manusia.

Temuan di klaster ini mendukung penelitian terdahulu dari Taner et al (2011), Chalid dan Yusuf (2014), dan Baeti (2013) bahwa pengangguran berpengaruh negatif signifikan terhadap IPM. Penelitian Chalid dan Yusuf (2014) serta Baeti (2013) memiliki beberapa persamaan dengan penelitian disertasi ini, misalnya sama-sama menggunakan metode regresi data panel dan mengambil obyek penelitian di level provinsi. Penelitian Baeti (2013) mengungkapkan bahwa di Provinsi Jawa Tengah secara umum jumlah pengangguran di semua kabupaten lebih besar daripada jumlah pengangguran di semua kota yang menunjukkan bahwa lapangan kerja di kota lebih memadai dibandingkan di kabupaten.

Perbedaan penelitian disertasi ini dengan kedua penelitian terdahulu tersebut adalah keduanya tidak menggunakan pendekatan klaster, tidak melakukan perbandingan, dan hanya meneliti provinsi secara umum. Adapun persamaannya terletak pada pendekatan model estimasi yang sama-sama menggunakan FEM sebagai pendekatan yang terbaik.

Adapun penelitian Taner et al (2011) mengambil sampel 30 negara yang tergabung dalam OECD (Organization for Economic Co-operation and Development) dengan periode pengamatan 10 tahun. Jadi dalam hal ini terdapat kesamaan yaitu menggunakan data panel hanya saja Taner et al 
(2011) tidak menguraikan secara rinci model estimasi terbaik yang digunakan. Adapun hasilnya sama, yaitu pengangguran berpengaruh negatif terhadap IPM.

Berdasarkan data profil ketenagakerjaan Jawa Timur tahun 2019, dari 20,76 juta orang yang bekerja di Provinsi Jawa Timur sebanyak 61,60 persen orang bekerja pada kegiatan informal. Yang termasuk kegiatan informal adalah: berusaha sendiri, berusaha dibantu buruh tidak tetap, pekerja bebas, dan pekerja keluarga/tidak dibayar. Di antara status pekerjaan utama kegiatan informal didominasi oleh berusaha dan dibantu buruh tidak tetap. Maka, pekerja di sektor kegiatan informal ini perlu diberikan pembinaan, pendampingan, dan pelatihan agar suatu saat berkembang menjadi sektor kegiatan formal dan mampu menyerap tenaga kerja lebih banyak lagi sehingga tingkat pengangguran semakin berkurang.

\section{c. Gini rasio berpengaruh positif signifikan terhadap IPM di Daerah Cepat Maju dan Cepat Tumbuh (High Growth High Income) di Jawa Timur}

Variabel gini rasio terbukti berpengaruh signifikan terhadap IPM di Daerah Cepat Maju dan Cepat Tumbuh berdasarkan nilai t statistik yang signifikan pada a 5\%. Apabila melihat tanda (arah) pada koefisien yang bertanda positif menunjukkan bahwa gini rasio berpengaruh positif signifikan terhadap IPM di klaster ini. Ketika gini rasio naik, di sisi lain IPM juga mengalami kenaikan. Dengan demikian Hipotesis 3 diterima (terbukti).

Gini rasio terbukti berpengaruh positif terhadap pembangunan manusia di Daerah Cepat Maju dan Cepat Tumbuh di Jawa Timur, mendukung pandangan positif Todaro dan Smith (2011) tentang ketimpangan. Menurut Todaro dan Smith ketimpangan lahir dari pertumbuhan ekonomi. Jadi, pada saat pertumbuhan ekonomi tinggi saaat itu juga gini rasio menjadi tinggi akibat meningkatnya pendapatan di masyarakat. Pada saat terjadi pertumbuhan ekonomi, pembangunan ekonomi yang pada hakikatnya bertujuan untuk membangun manusia (mewujudkan kesejahteraan) dapat diwujudkan. Hal ini berarti kenaikan gini rasio akan berjalan beriringan dengan peningkatan kesejahteraan manusia sampai pada titik tertentu pencapaian gini rasio. Peningkatan gini rasio biasanya disebabkan peningkatan pendapatan di masyarakat. Peningkatan pendapatan mendorong peningkatan pengeluaran konsumsi. Semakin besar pengeluaran konsumsi menunjukkan kehidupan masyarakat semakin sejahtera.

Dengan kata lain, ketimpangan pendapatan tidak selalu merupakan hal buruk, karena terdapat kesempatan untuk memberi imbalan bagi mereka yang bekerja keras dan mengambil risiko. Kerja keras dan inovasi menguntungkan masyarakat karena dapat menciptakan barang dan jasa baru yang bisa dinikmati semua orang sehingga memberi kontribusi ekonomi lebih luas. Kemampuan pemerintah menyediakan pelayanan publik pun menjadi lebih besar. Jika kemudian ketimpangan ini menimbulkan kesenjangan di antara mereka yang bekerja keras dan kurang keras, maka dapat dibenarkan dan bahkan diinginkan.

Salah satu faktor penyebab ketimpangan semakin tinggi di Daerah Cepat Maju dan Cepat Tumbuh adalah kondisi pasar tenaga kerja yang terbagi menjadi pekerja berketerampilan tinggi yang upahnya semakin meningkat, dan pekerja yang tidak memiliki kesempatan untuk mengembangkan keterampilan tersebut sehingga terjebak dalam pekerjaan berproduktivitas rendah, informal, dan berupah rendah. Calon pekerja berketerampilan tinggi di daerah-daerah biasanya memberanikan diri untuk merantau ke kota dengan tujuan mendapatkan pekerjaan yang lebih layak dengan jumlah penghasilan yang lebih memuaskan. Umumnya upah bekerja di kota lebih menjanjikan dibandingkan upah di desa. Selain itu ketimpangan menjadi lebih tinggi karena didorong oleh praktik-praktik korupsi. Sesuai data dari Dinas Komunikasi dan Informatika Provinsi Jawa Timur, per bulan Februari tahun 2019, setidaknya terkonfirmasi adanya enam kasus korupsi yang melibatkan pemerintah daerah di klaster Daerah Cepat Maju dan Cepat Tumbuh, seperti : kasus di Kabupaten Mojokerto, Kota Blitar, Kota Malang, Kota Mojokerto, Kota Madiun, dan Kota Batu (http://kominfo.jatimprov.go.id/read/umum/ini-hasil-verifikasi-kpk-program-pemberantasan-korupsiterintegrasi-2018-jatim, diakses 15 Agustus 2020). 
Manusia maju (modern) umumnya ditemukan di wilayah perkotaan. Bank Dunia (2019) mengungkapkan bahwa ketimpangan pendapatan lumrah terjadi di wilayah perkotaan atau wilayah maju. Dan hal ini terjadi di klaster Daerah Cepat Maju dan Cepat Tumbuh di Jawa Timur, gini rasio terbukti berpengaruh positif signifikan terhadap pembangunan manusia.

Temuan ini mendukung hasil penelitian Rustariyuni (2014) yang penelitiannya dilakukan di Provinsi Bali. Gini rasio terbukti berpengaruh positif signifikan terhadap IPM di Provinsi Bali. Persamaan penelitian ini dengan Rustariyuni adalah dalam hal penggunaan metode regresi data panel. Adapun perbedaannya adalah Rustariyuni mencukupkan pada pendekatan model CEM saja, sedangkan penelitian ini menggunakan tiga pendekatan dalam regresi data panel yaitu CEM, FEM, dan REM untuk mendapatkan model estimasi yang terbaik. Dan model IPM terbaik yang dihasilkan untuk Daerah Cepat Maju dan Cepat Tumbuh yaitu menggunakan pendekatan Fixed Effect (FEM).

\section{d. Kepadatan penduduk berpengaruh positif signifikan terhadap IPM di Daerah Cepat Maju dan Cepat Tumbuh (High Growth High Income) di Jawa Timur}

Variabel kepadatan penduduk terbukti berpengaruh signifikan terhadap IPM pada Daerah Cepat Maju dan Cepat Tumbuh berdasarkan nilai t statistik yang signifikan pada a $5 \%$. Apabila melihat tanda (arah) pada koefisien yang bertanda positif menunjukkan bahwa kepadatan penduduk berpengaruh positif signifikan terhadap IPM di klaster ini. Ketika kepadatan penduduk meningkat di sisi lain IPM juga mengalami peningkatan. Dengan demikian Hipotesis 4 diterima (terbukti).

Temuan ini sesuai dengan teori dari Sukirno (2019) bahwa kepadatan penduduk dapat menjadi pendorong ekonomi. Wilayah padat penduduk seringkali menjadi magnet bagi para pelaku ekonomi karena menjanjikan potensi pasar yang luas sekaligus pasar tenaga kerja yang besar dan kompeten. Kompetensi dan skill dimiliki karena pasar tenaga kerja yang besar menuntut calon tenaga kerja untuk memiliki kemampuan lebih agar mampu berkompetisi memasuki lapangan kerja. Wilayah padat penduduk memiliki produktivitas yang lebih tinggi sehingga menyebabkan pertambahan produksi yang lebih cepat dibandingkan pertambahan tenaga kerja. Tentu hal ini sangat menguntungkan bagi dunia industri, tingkat kegiatan ekonomi, dan pertambahan produksi nasional.

Hasil penelitian ini juga mendukung temuan dari Qasim dan Chaudry (2015) yang mengadakan penelitian di Districts Punjab Pakistan dan menghasilkan temuan bahwa kepadatan penduduk berpengaruh positif signifikan terhadap IPM karena kepadatan penduduk dapat mendorong produktivitas, memacu inovasi di bidang teknologi, dan memberi insentif yang besar untuk investasi. Penelitian Qasim dan Chaudry juga menggunakan metode regresi namun dengan data cross section.

Di sisi lain hasil penelitian ini bertentangan dengan hasil penelitian yang dilakukan Oktavilia et all (2018) yaitu bahwa di Indonesia kepadatan penduduk justru berpengaruh negatif signifikan terhadap Indeks Pembangunan Manusia. Untuk meningkatkan kualitas manusia Indonesia Oktavilia et al (2018) memberikan solusi pendistribusian penduduk ke daerah-daerah yang kepadatan penduduknya rendah.

\section{SIMPULAN DAN SARAN}

Berdasarkan pembahasan, beberapa hal yang dapat disimpulan dari hasil penelitian ini adalah:

1. Pengangguran, gini rasio, dan kepadatan penduduk secara simultan berpengaruh signifikan terhadap IPM di Daerah Cepat Maju dan Cepat Tumbuh (High Growth High Income) di Jawa Timur. Semakin rendah tingkat pengangguran, semakin tinggi gini rasio dan semakin tinggi kepadatan penduduk maka IPM di klaster ini akan semakin tinggi. Daerah-daerah yang tergabung di klaster ini memiliki ciri pertumbuhan ekonomi dan IPM di atas rata-rata Jawa Timur dan merupakan pusat perekonomian di Jawa Timur sehingga menjadi magnet bagi masyarakat Jawa Timur untuk 
melakukan urbanisasi. Semakin banyaknya masyarakat urban, semakin menambah kepadatan penduduk di kuadran ini, pun yang tidak terserap lapangan kerja menambah jumlah pengangguran di wilayah ini. Wilayah maju juga identik dengan kehidupan yang kompetitif sehingga gini rasio di wilayah maju umumnya tinggi. Kontrol yang ketat terhadap gini rasio dan kepadatan penduduk serta angka pengangguran berpengaruh nyata terhadap IPM di wilayah ini.

2. Pengangguran berpengaruh negatif signifikan terhadap IPM di Daerah Cepat Maju dan Cepat Tumbuh (High Growth High Income) di Jawa Timur. Semakin rendah tingkat pengangguran maka IPM di klaster ini semakin tinggi. Daerah di klaster ini merupakan kawasan perkotaan, pusat industri, dan memiliki potensi perikanan dan potensi garam sehingga mampu menyerap lebih banyak pengangguran. Ketika pengangguran yang terserap lebih banyak maka jumlah pendapatan di masyarakat semakin bertambah sehingga kemakmuran (pembangunan manusia) semakin meningkat. Sebaliknya, peningkatan pengangguran yang dipicu oleh masyarakat urban yang tidak terserap lapangan pekerjaan justru akan menurunkan tingkat kesejahteraan masyarakat yang berada di wilayah ini. Oleh karena itu penurunan angka pengangguran berpengaruh nyata terhadap peningkatan IPM di wilayah ini.

3. Gini rasio berpengaruh positif signifikan terhadap IPM di Daerah Cepat Maju dan Cepat Tumbuh (High Growth High Income) di Jawa Timur. Semakin tinggi gini rasio, semakin tinggi pula IPM, yang menunjukkan daerah tersebut semakin maju. Peningkatan gini rasio dapat disebabkan oleh peningkatan pendapatan masyarakat. Ketika pendapatan meningkat maka pengeluaran konsumsi juga semakin meningkat, menyebabkan perputaran ekonomi semakin cepat dan kesejahteraan masyarakat meningkat. Gini rasio di Jawa Timur stabil dalam kategori sedang, sehingga dapat diambil sisi positif dari ketimpangan pendapatan di kategori sedang ini, yaitu dapat merangsang ideide, kreativitas, dan inovasi agar masyarakat mendapat imbalan dari kerja kerasnya dan mampu mengurangi ketimpangan itu sendiri. Peningkatan gini rasio akan berdampak positif jika diimbangi dengan peningkatan produktivitas. Daerah-daerah pada klaster ini memiliki tingkat produktivitas yang tinggi karena merupakan pusat ekonomi dan perindustrian di Jawa Timur.

4. Kepadatan penduduk berpengaruh positif signifikan terhadap IPM di Daerah Cepat Maju dan Cepat Tumbuh (High Growth High Income) di Jawa Timur. Semakin padat suatu daerah, semakin tinggi pula IPM, menunjukkan umumnya daerah padat penduduk adalah daerah maju dan daerah industri. Suatu wilayah yang padat penduduk menjadi pasar potensial untuk semakin bertumbuhnya perekonomian masyarakat karena masyarakat mendapatkan peningkatan penghasilan. Oleh karena itu kepadatan penduduk berpengaruh nyata terhadap tingginya IPM di wilayah ini.

Berdasarkan simpulan, maka beberapa saran yang dapat dijadikan pertimbangan oleh Pemerintah Provinsi dan Pemerintah Kabupaten/Kota di Jawa Timur adalah:

1. Terkait pengangguran, gini rasio, dan kepadatan penduduk secara simultan berpengaruh terhadap IPM di Daerah Cepat Maju dan Cepat Tumbuh (High Growth High Income) di Jawa Timur, maka isu pengangguran, gini rasio, dan kepadatan penduduk perlu mendapat prioritas untuk meningkatkan pembangunan manusia.

2. Angka pengangguran di Daerah Cepat Maju dan Cepat Tumbuh (High Growth High Income) di Jawa Timur dapat dikurangi dengan berbagai upaya, diantaranya : 1) Meningkatkan akses angkatan kerja terhadap lapangan pekerjaan di sektor formal melalui pengembangan jejaring informasi pasar kerja, bursa kerja online, job fair, dan magang; 2) Mengembangkan usaha produktif melalui kewirausahaan serta memberikan pembinaan kewirausahaan pada angkatan kerja yang belum terserap lapangan kerja utamanya pembinaan kewirausahaan yang berbasis teknologi informasi; 3) Mengoptimalkan dan mengembangkan kapasitas Balai Latihan Kerja dalam memberikan pelatihan berbasis kompetensi dan uji kompetensi menuju standardisasi internasional; 4) Mengupayakan untuk menarik lebih banyak tenaga kerja di sektor produktif dan sektor informal, 5) Mengoptimalkan peran pondok pesantren dalam meningkatkan keterampilan para santri dengan memberikan bantuan sarana dan prasarana untuk usaha produktif; 6) Mengembangkan potensi lokal daerah melalui inkubator bisnis 
yang berjenjang agar dapat membuka lapangan pekerjaan baru untuk menyerap angka pengangguran yang cukup tinggi; 7) Menjalin kemitraan antara instansi terkait, perguruan tinggi serta industri (Corporate Social Responsibility) untuk meningkatkan link and match antara kurikulum lembaga pendidikan dan lembaga pelatihan dengan kebutuhan di dunia kerja dan dunia usaha; 8) Mengembangkan ketenagakerjaan di sektor informal dengan melatih tenaga kerja mandiri untuk mengadopsi teknologi terapan tepat guna; 9) Meningkatkan pelayanan dan perluasan kesempatan kerja ke luar negeri dengan perlindungan hukum yang memadai; 10) Menawarkan program transmigrasi yang selektif dengan kompensasi lahan produktif.

3. Gini rasio di Daerah Cepat Maju dan Cepat Tumbuh (High Growth High Income) di Jawa Timur perlu dipertahankan berada pada kategori "sedang" pada rentang 0,35-0,5. Jurang ketimpangan dapat dikurangi melalui pemerataan proses pembangunan yang disesuaikan dengan kebutuhan dan potensi tiap-tiap daerah kabupaten/kota. Selain itu akses penduduk miskin terhadap kredit mikro tanpa bunga perlu ditingkatkan dengan mengembangkan kerjasama dengan lembaga-lembaga pembiayaan syariah.

4. Kepadatan penduduk di Daerah Cepat Maju dan Cepat Tumbuh (High Growth High Income) di Jawa Timur sebagai potensi sumber daya manusia yang melimpah perlu dikelola dengan baik, dengan cara tetap menjaga keseimbangan antara faktor manusia dan ketersediaan faktor sumber daya alam. Artinya, meningkatnya kepadatan penduduk harus diiringi dengan meningkatnya kepedulian terhadap lingkungan. Kepadatan penduduk tidak menjadi penyebab degenerasi sumber daya alam. Potensi kepadatan penduduk perlu disinergikan dengan daerah-daerah sekitar sehingga daerah berpenduduk padat bisa menjadi kutup pertumbuhan yang menghasilkan tricle down effect bagi daerah-daerah yang berdampingan dengannya, misalnya menumbuhkan potensi aglomerasi. Akses cakupan terhadap layanan air minum dengan harga terjangkau, sanitasi yang layak, serta perumahan yang layak huni perlu ditingkatkan bagi seluruh masyarakat khususnya yang berpenghasilan rendah misalnya melalui pengadaan Rumah Susun untuk mengurangi pemukiman kumuh di daerah padat penduduk.

\section{REFERENCES/DAFTAR PUSTAKA}

Amir, M. F. (2015). Menulis Tesis dan Disertasi (Mengoptimalkan Keefektifan Berpikir). Jakarta: Mitra Wacana Media.

Anderson, T. (2014). The Case for an Enhanced Human Development Index. University of Sydney, Sydney, Australia.

Baeti, N. (2013). Pengaruh Pengangguran, Pertumbuhan Ekonomi, dan Pengeluaran Pemerintah terhadap Pembangunan Manusia Kabupaten/Kota di Provinsi Jawa Tengah Tahun 2007-2011. Economics Development Analysis Journal Vol 2 No 32013 , 85-98.

Bintang P, M., Ismail, N., \& Indra. (2015). Determinan Indeks Pembangunan Manusia : Analisa Pendekatan Maqasid Syari'ah al Ghazali (Studi Kasus : Negara-neraga OKI). Eksyar Vol 2 No 2 November 2015, 512-534.

BPS. (2015). Indeks Pembangunan Manusia 2014. Jakarta: Badan Pusat statistik.

Chalid, N., \& Yusuf, Y. (2014). Pengaruh Tingkat Kemiskinan, Tingkat Pengangguran, Upah Minimum Kabupaten/Kota dan Laju Pertumbuhan Ekonomi terhadap Indeks Pembangunan Manusia di Provinsi Riau. Jurnal Ekonomi Vol 22 No. 2 Juni 2014 , 1-12.

https://kominfo.jatimprov.go.id/read/umum/ini-hasil-verifikasi-kpk-program-pemberantasan-korupsiterintegrasi-2018-jatim, diakses 15 Agustus 2020.

Oktavilia, S., Puspita, D. W., Firmansyah, \& Sugiyanto, F. (2018). The Relationship Between Environmental Degradation, Poverty, and Human Quality in Indonesia. E3S Web of Conferences 73, 10020 (2018) ICENIS 2018 (pp. 1-3). EDP Sciences. 
Qasim, N., \& Chaudary, A. R. (2015). Determinants of Human Development Disparities : A Cross District Analysis of Punjab Pakistan. The Pakistan Development Review 54:4, Part II (Winter 2015) , 427-446.

Rustariyuni, S. D. (2014). Pengaruh Gini Ratio, Pengeluaran Non Makanan Per Kapita, Belanja Daerah dan Laju Pertumbuhan Ekonomi pada Indeks Pembangunan Manusia Kabupaten/Kota di Provinsi Bali Periode 2004-2012. Jurnal Piramida Vol X No 1 Tahun 2014 , 45-55.

Sari, I.P. (2020). Analisis Determinan Indeks Pembangunan Manusia dan Implikasinya terhadap Kemiskinan di Jawa Timur dengan Pendekatan Klaster Berbasis Tipologi Klassen. Disertasi. Program Doktor IImu Ekonomi Program Pascasarjana. Universitas Borobudur.

Sembada, Y. S., Tiara, Y., \& Fauzan, A. (2019). Effect of Gross Regional Domestic Product, Life Expectancy, and Illiterate Population on Human Development Index in Indonesia Using Data Panel Regression Analysis. Asia Young Scholars Submit (AYSS) .

Shah, S. (2016). Determinant of Human Development Index: A Cross-Country Empirical Analysis. Munich Personal Rec Archive .

Sukirno, S. (2019). Makro Ekonomi Teori Pengantar Edisi Ketiga. Jakarta: PT RajaGrafindo Persada.

Taner, M. T., Sezen, B., \& Mihci, H. (2011). An Alternative Human Development Index .South East European Journal of Economics and Business · April $2011,45-60$.

The World Bank. (2019, April 3). Poverty. Retrieved July 13, 2019, from www.worldbank.org: https://www.worldbank.org/en/topic/poverty/overview

Todaro, M. P., \& Smith, S. C. (2011). Pembangunan Ekonomi Edisi Kesebelas Jillid 1. Jakarta: Erlangga.

Yolanda, Sari, Mulatsih, \& Massora. (2020). The Human Development and Poverty Allevation Based on Klassen's Typology : Case Study of East Java Province. JARDCS Vol 12 Issue 7. Page 477483. DOI : 10.5373/JARDCS/V1217/20202029. 